Bennett, A.F., Poleward heat fluxes in Southern Hemisphere oceans, J. Phys. Oceanogr.. 8 $785-798,1978$.

Bernstein, R.L., and w.B. White, Meridional eddy heat flux in the Kuroshio Extengion 1982 .

Bryan, $\mathrm{K}$. , Messurements of meridional heat trangport by ocean currents, J. Geophys. Reg. 67, 3403-3414, 1962

Bryan, K., Poleward heat transport by the ocean: observations and models. Ann. Rev. Earth Planet. Sc1. . 10, 15-38, $\frac{19}{1982 a}$

Bryan, K., Seasonal variation in meridional overturning and poleward heat transport In the Atlantic and Pacific Oceans: A model atudy, J. Mar. Res., 40 (Sup1. Vol.) 39-53, $1982 b$.

Bryan, K. and L.J. Lewls, A water mass model of the World Ocean, J. Geophys. Res., 84 (C5) 2503-2517, 1979

Bryden, H.L., Poleward heat flux and conversion of avallable potential energy in Drake

Bryden, H.L., Ocean heat transport, Papers of

the JSC/CCCO Meeting on Time Ser apers of the Jsc/ccco Meeting on Time Serles of Ocean Program, Publ. 21, IOC, Par1s, hMo, Ceneva, Progr.

Bryden, H.L., and M.M. Ha11, Heat transport by currents across $25^{\circ} \mathrm{N}$ latitude in the Atlantic Ocean. Science, 207, 884-886, 1980,

Bunker, A., Computations of surface energy flux and annual alr-sea interaction cycles of the North Atlantic Ocean, Mon. Weather Rev. $104,1122-1140,1976$

Campbeil, G.G., Energy transport within the earth's atmosphere-ocean system from a climate point of view, Ph.D. Thesis, Colorado State Untvergity, Fort Collins, Co.. 198I.

De Szoeke, R.A. and M.D. Levine. The advective flux of heat by mean geostrophte motlons in the Souther

Dobson, F.. F.P. Bretherton, D.M. Burridge, J.

Crease, F.B. Kraus, and T.H. Vonder Har. The 'Cage' Experiment: A Feastbllity Study, Geneva, $95 \mathrm{pp}$. 1982.

Fu, L.L., The general c1rculation and meridional heat trangport of the subtropical South Atlantic deternined by Inverse methods, J.
Phys. Oceanogr.: 11, 1171-1193, 1981. 11ater, F.C. Aclantic Ocean Atlas of Temperature and Salinity Protiles and Data from 58 ,

Series 1,209 pp. 1960. C1, D.T., and J.M. Toole, The Antarctic Circumpolar Current and the oceanic heat (Vo1.40, Supp1.), 183-197, 1932.

Godfrey, J.s., and T.J. Golding, The Sverdrup relation in the Indtan Ocean, and the effect of the Pacific. Indian Ocean through-flow on Indian Ocean circulation and on the East Austral1an Curtent, J. Phys. Oceanogr. , 11,

HaIl, M.M., and H.L. Bryden, Direct estimates and mechanisens of ocean heat transpor Deep-Sea Reg., 29, 339-360, 1982.

Hastenrath, s., veat budget of tropical ocean and atmosphere, $\underline{\mathrm{J}}$. Phys. Oceanogr., $\underline{10}$

Hastenrath, s., On meridional heat transports In the World Ocean, J. Phys. Oceanogr., $\underline{12}$

Hasrenrath, S. and P. Lamb, Climatic Atlas of the Tropical Atlantic and Eastern Pacific Press, 105 pp, 1977 .

Jupg, G.H.. Energy transport by atr and sea. Section XIV of The Dynamic North, look section XIV of the Dynamic North, Book $I$ of Naval Operations for Polar Projects, 19 pp, 1956.

Luyten, J. and H. Stommel, Recirculation reconsidered. J. Mar. Res., 40, (Suppl. Vol.) $407-426,1982$.

Meehl, G.A., W.M. Washington, and A.J. Semtner, Experiments with a global ocean model driven by observed atmospheric forcing, J. Phys. Oc eanogr., 12, 301-312, 1982 .

MIIIET, J.R.; G.L. Russeli, and L-C Tsang, Annual oceanic heat transporto couputed from an atmospher tc 1982 , In press.

variallity a.s. Richardson, Seasonal of the Florida Current, J. Mar. Res.' 31, 144-167, 1973.

Clt, A.H. Global Atmosphere Circulation Stat-

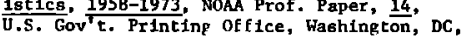
323 Pp, 1982.
Roemmich, D., Estimation of meridional heat lux 1n the North Atlantic by Inverse methods, J. Phys. Ocean.. 10, 1972-83, 1980

rmiento, J.L., and $K$. Bryan, An ocean transport model for the North Aclantic. J. Geophys.

the poleward heat flus to low-frequency current fluctuations in the Drake Passage, J. Phys

Stomme1, H., Asymmetry of 1nteroceanic freshwater and heat fluxes, Proc. Nat. Acad. Sci. USA, 77(5) 2377-2381, 1980 .

Stoumel, H., and G.T. Caanady, Relation between the T-S curve and global heat and atmogpheric water transporta, J. Geophys. Res.. 85 , (C1)

Stomel, H., and G. Veronis, Variational inverse method for study of ocean clrculation, Deep Sea Res., 28A, 1147-1160, 1981.

Trenberth, K.E., Mean annual poleward energy tramsports by the oceans fn the oouthern
hemisphere, Dyn. Atmos. Oceang, 4. 57-64, 1979 .

Vonder Har, T.H., and A. Oort, New estimate of annual poleward energy transport by nor thern hemisphere oceans, I. Phys. Oceanogr. 3. 169-172, 1973 .

Weare, B., P.T. Strub, and M.D. Samuel, Annual mean surface heat fluxes in the tropical Pac1fic Ocean, J. Phys. Oceanogr., 11, 705-

Wunsch. C., Meridional heat flux of the North Atlantic Ocean, Proc. Nat. Acad. of Sciences.

insch, C.. The North Atlantic general circulatherse methods, Rev. Geophys. and Space Phys., 16,

Wunsch, C., D. Hu, and B. Grant, Mass, heat, salt and nutrient fluxes in the South Pacific Ocean, J. Phys. Oceanogr., (In presg) 1983.

Whlst, G., and A. Defant, Scientific Regults of the German Atlantic of the Regearch Vesse1

(Rece1ved October 29, 1982, accepted January $6,1983$. )

REVIEWS OF GEOPHYSICS AND SPACE PHYSICS, VOL. 21, NO. 5, PAGES 1137-1148, JUNE 1983

U.S. NATIONAL REPORT TO INTERNATIONAL UNION OF GEODESY AND GEOPHYSICS 1979-1982

\title{
EQUATORIAL OCEANOGRAPHY
}

Mark A. Cane

Dept. of Meteorology and Physical Oceanography, MIT, Cambridge, MA 02139

\section{E.S. Sarachik}

Center for Earth and Planetary Physies, Harvard Oniv., Cambridge, MA 02138

Introduction

Interest and activity in the equatorial oceans (defined arbitrarily as that part of the oceans within ten degrees of the equator) have undergone a remarkable expansion in the last four years. The previous IOGG report (O'Brien, 1979) listed about one hundred references - the present one lists over two hundred and fifty. Among the many reasons for this growth, a primary one is the realization of the rapid nature of equatorial responses. The vanishing of the Coriolis parameter in the presence of density

Copyright 1983 by the American Geophysical Union.

Paper number 3R0051.

0034-6853/83/003R-0051\$15.00 stratification means that the ocean can respond strongly to basinwide winds on the climatically important, and observationally accessible, annual and interannual time scales. This realization has taken hold as the result of an interplay among theory, modelling and observation.

Linear wave ideas have provided a simple framework and common language to discuss a wide range of equatorial phenomena. In particular, the equatorial Kelvin wave, which allows locally forced wind changes to be rapidly communicated to the east of the forcing region, has been a particularly fruitful concept in equatorial oceanography. L1near and nonlinear numerical models ranging from single layer shallow water models to full general circulation models have built upon these linear wave concepts to elucidate the roles of stratification, mixing, and 
non-linearity in the dynamics of a wide variety of phenomena in the equatorial oceans. In addition, extensive observations taken during field programs in all three oceans have become avallable in the last four years: the GARP Atlantic Tropical Experiment (GATE) in the Atlantic (see the GATE Atlas: Duing, Ostapoff and Merle, 1980 and the GATE Supplements to Deep-Sea Research; Duing, 1980, and Siedler and Woods, 1980), the Indian Ocean Experiment (INDEX, see the August 1,1980 issue of Satence); and the intensive year 1979-1980 of the First GARP Global Exper1ment (FGGE, see McCreary, Moore and Witte, 1981). In addition, preliminary theoretical and observational work is regularly and efficiently transmitted by the Tropical Ocean-Atmosphere Newsletter (edited by D. Halpern, JISAO, University of Washington, Seattle).

Interest in equatorial oceanography has also intensified outside the oceanographic community. All available data shows that the tropical ocean dominates ocean beat transport both in the mean and in annual variations (see Bryan, 1982, for a recent review) and is therefore a major component of the climate system. It is only within the last few years that a major role for the equatorial ocean in interannual global climate variability has been more than simply suggested. Horel and Wallace (1981) showed that periods of low Southern Oscillation, known to coincide with those periods of anomalous warmings of the equatorial Pactfic called El Nino, show correlation with anomalous winter climate over the United States and that this anomalous mid-latitude winter response is consistent in its geographical pattern with having been forced by atmospheric thermal anomalies associated with the warm Pacific. While the correlations are not large, and the atmospheric forcing mechanisms by no means completely understood, the possibility of predicting anomalous conditions over the U.S. during the winter following the onset of El Nino (e.g. Barnett, 1981a) seems to have galvanized both the meteorological and oceanographic communities into a burst of research into the origins of interannual sea surface temperature (SST) variability in the Pacific and into the mechanisms of atmospheric telecommunications from equatorial to midlatitude regions.

In order to usefully revlew D.S. progress in equatorial oceanography in the limited space available to us, we focus our primarily on the low frequency response of upper equatorial oceans to forcing by the wind. We perceive this as the unifying theme of equatorial oceanography during the previous four years. A major development in this vein, unprecedented in large-scale oceanography, is the attempt to simulate ocean variability by forcing ocean models with real winds and verifying the model response by comparing to oceanographic data records at selected points. While the ocean models used in these attempts have been highly idealized and the quality of wind data dubious at best, the initial results have been encouraging. This attempt at simulation brings observation and theory into an intimacy rare in oceanography and will, we hope, provide a continuing arena for testing our understanding of dynamic and thermodynamic processes.

We begin this review by discussing varia- tions of thermocline depth, mid-ocean currents, and boundary currents. We will then review a problem which has just begun to receive serious attention, namely the factors that determine SST variability in equatorial oceans. We then discuss the status of our understanding of the most spectacular manifestation of SST variability, the El Nino - Southern Oscillation phenomenon. We proceed to discuss the problem of observing the surface winds, which we regard as a fundamental factor limiting our understanding of the equatorial oceans. Finally, we will try to identify those current trends that we expect to bear fruit by the time of the next IUGG report, and some directions for the more distant future.

\section{Thermocline Variations}

The thermocline in equatorial oceans tends to be quite shallow, with an average depth of about $100 \mathrm{~m}$. Because of the action of the easterly trade winds, the mean thermocline tends to be deeper in the western parts of the ocean and shallower in the east. It has proved illuminating, over the last decade, to consider a model of the equatorial ocean consisting of a homogeneous light fluid, of mean depth of order $100 \mathrm{~m}$, overlaying a heavier fluid. The interface between these fluids then represented the thermocline, and to the extent that motions in the fluid below the interface are small, the motion of the upper fluid satisfies the shallow water equations. In the presence of steady zonal winds, a no motion solution to the shallow water equations is ' $\mathrm{gg}^{\prime}\left(\mathrm{h}^{2}\right)_{\mathrm{x}}=\tau(\mathrm{x})$ where $\mathrm{h}$ is the depth to the interface and $T(x)$ is the wind stress. The long-term mean Pacific thermocline does indeed seem to agree with this simple formula, even though the Paciflc in the mean has a wind-driven surface current and an equatorial undercurrent, and therefore is far from motionless. The success of the simple shallow water model at modelling variations of thermocline depth has been quite striking, but there is no consensus on why it works as well as it does. Certainly the currents that the shallow water models predict are at odds with observations of equatorial currents (see next section for more detalls).

Equatorial subsurface measurements have been taken infrequently in the Atlantic and Pacific, and hardly at all in the Indian Ocean. There is, however, enough climatological data in the Pacific and Atlantic to at least give the broad outline of seasonal varlability. Meyers (1979b) examined the climatological monthly variation of the $14^{\circ} \mathrm{C}$ isotherm on the equator, which is near the bottom of the thermocline in the Pacific. He finds that the variability with respect to the mean is relatively small and that the largest seasonal variability is in the eastern Pacific. Tsuchiya (1979) examined the geopotential gradient in the eastern Pacific and found it to be roughly in phase with the seasonal zonal winds. Both of these results are complementary to Horel's (1982) results which shows most of the seasonal variability of SST to be confined to the eastern Pacific. In the Atlant1c, Merle (1980b, 1980c) finds that the seasonal variation of the $23^{\circ} \mathrm{C}$ isotherm (marking the upper part of the equatorial thermocline) is 
not small compared to the mean and that when the mean zonal winds across the equatorial Atlantic are weak (in February-March), the thermocline becomes almost flat. These results are in agreement with the previous results of Katz et al (1977) for the zonal pressure gradient in the equatorial Atlantic. Merle also finds that the varlations in heat content are in phase with the thermocline variations and that they are an order of magnitude larger than, and out of phase with, the vertical heat fluxes through the sea surface. This implies that on a seasonal time scale at least, heat content variations are dynamically forced and that the surface heat flux does not cause these heat content variations but, rather, responds to the dynamically induced SST variations accompanying the heat content changes. Further, by taking zonal averages across the entire Atlantic, Merle finds that there are annual heat content variations in the zonal average implying that heat is not simply sloshed east-west, but must also be redistributed meridionally. This latter result is consistent with a study by Katz (1981) of dynamic topography in the western Atlantic show1ng that the entire dynamic topography pattern (consisting of a mean equatorial ridge at $4 \mathrm{~N}$ and a trough at $10 \mathrm{~N}$ between which geostrophically flows the North Equatorial Counter Current) flattens out in early spring and deepens in late summer.

Theoretical approaches to understanding thermocline variations have been of two major types: those using 1dealized winds blowing over shallow water models and those using approximations to the real winds blowing over shallow water models. The first type of calculation is done to understand the basic dynamics of forced response, while the second type is done to compare response to observations.

An lllustration of the first type of calculation is Cane and Sarachik (1981) who forced a linear equatorial shallow water model with periodically varying zonal winds of Gaussian form in the meridional direction, and independent of zonal coordinate. They solved for the response analytically over a wide range of parameters. The response for parameters characteristic of annual forcing over the Atlantic showed a remarkable (and perhaps fortuitous) agreement with many of the features of the annual Atlantic response as described by Merle $(1980 \mathrm{c})$. But more 1mportant, the calculation showed that response to periodic forcing differed in fundamental ways frow response to 1mpulstve forcing. In particular, the response to periodic forcing may be considered the standIng sum of local and boundary responses, all at the forcing frequency, and illustrated many of the interference effects first predicted by Schopf, Anderson and Smith (1981). Furthermore, It showed that the greater seasonality of response of the Atlantic versus the Pacific could not be attributed to the smaller size or greater memory of the Atlantic (Philander, 1979) since "memory" is a concept concept valid only in intilal value problems, not in periodic response problems. The difference in the response of the two oceans is attributable to the greater seasonality of the winds over the Atlantic. The calculations also indicated that periodic response of the thermocline depends strongly on the winds within ten degrees of the equator and only weakly on winds beyond ten degrees.

Kindle (1979) and Busalacchl and O'Brien (1980) force a shallow water model of the Pacific with an approximation to the annual and semi-annual winds. They both find that the semi-annual response of the thermocline in the eastern Pacific is forced by the semi-annual winds in the central Pacific. Rindle (1979) achieves a better overall simulation of equatorlal thermocline variability in the east primarily, we believe, because Busalacchl and o'Brien (1980) extended the winds observed between +3 degrees and uniformly extended poleward; as indicated earlier, the winds between 3 and 10 degrees do affect the equatorial response. On the other hand, using mean monthly winds over the entire Pacific, Busalacchi and O'Brien achieve impressive agreement of the meridional topography of the thermocline and its observed annual variation with observation.

In the Atlantic, Busalacchi and Picaut (1982) and Cane and Patton (1982) force with climatological monthly winds and compare with observations at Abijan on the northern coast of the Gulf of Guinea. Both are able to simulate the annual variation well and both conclude, by dividing up the wind fleld geographically, that the response is due to the wind field across the entire ocean and not just to wind changes in the Western Atlantic as had been previously suggested. There is no special contribution from the local winds at the Guinea coast.

Finally, Busalacch1 and O'Brien (1981) force the linear shallow water model of the Pacific with a decade of observed winds subjectively analyzed to fill gaps (Goldenberg and O'Brien, 1981), and compare to a decade of tide gauge observations of sea surface taken in the Galapagos. To the extent that motion is confined to a single baroclintc mode, sea surface variability is a proxy for themocline variabil1ty. The results show broad agreement with the sea surface interannual variability in that the model broadly reproduces the interannual cold and warm periods. There are obvious differences however: the simulated variability seems to have shorter time scales than observed and there are epochs of cold or warm water that the simulation misses completely. Considering that the winds are of low quality, that the model uses a single vertical mode where perhaps two or more are called for, and that the verification data for themocline displacement is a proxy, we take the results to be encouraging.

These attempts at simulation point to two important needs that currently exist, and have to be met before any further progress can take place. First, an accurate wind data set over the surface of the ocean over at least an annual cycle, and second, a complete thermocline depth data set simultaneous with the winds. Until both of these data sets are available, the confrontation between theory and experiment must necessarily be incomplete. It should be noted that two field programs are due to be performed in 1983, the U.S. Program SEQUAL (Seasonal Equatorial Atlantic Experiment) and the French program FOCAL (French Ocean Climate Atlantic exper- 
iment) which have, as one of their goals, the acquisition of simultaneous wind and thermocline data set for the equatorial Atlantic over a complete annual cycle.

\section{Equatorial Currents}

McCreary (1981a,b) has proposed an Interesting conceptual model for the steady equatorial undercurrent. The response of a linear inviscid ocean to a zonal wind independent of the meriodional coordinate would be a motionless Sverdrup balance in which the wind stress is opposed by the pressure gradient force. In McCreary's model the graver vertical modes are in such a Sverdrup balance, while for the higher modes the driving is balanced by the dissipation of heat and momentum. The result is a zonal fet -- an undercurrent -- centered in the model thermocline. This work shows how friction and stratification can act in concert to determine the characteristics of the undercurrent. The form chosen for the vertical viscosity and diffusion, however, is a function of the stratification, making the two influences Inseparable. McPhaden (1981) has proposed a linear model that uncouples the friction from the stratification, though not the thermal diffusion.

The models mentioned in the preceding paragraph both neglect nonlinear terms, which are easily shown to be order one near the equator. The nonlinear studies of Cane $(1979,1980)$ and Philander and Pacanowsk1 $(1979,1981)$ have enphasized the role of the meriodional circulat1on, especially the vertical advection of momentum. In a model with two homogeneous levels above the thermocline, Cane (1980) pointed out the differing effects of this term with easterlies and westerlies and used the results to explain the observed behavior of equatorial currents in the Indian Ocean (also see McPhaden, 1982b). Philander and Pacanowsk1 (1979,1981) extended these results to a multilevel strat1fied model. The papers referenced in this paragraph combine these nonlinear ideas with linear wave theory to explain the temporal behavior of the undercurrent and associated equatorial c1rculation. Cane (1979) showed that the linear ideas explained the establishment of the pressure gradient, which is crucial for establishing the meridional circulation and the undercurrent.

In the nonlinear meridional wind case the meridional advection of momentum destroys the symmetry of the linear solution and results in a strong eastward jet downwind of the equator. As a parcel of fluid moves meriodionally it picks up energy from the wind and as it moves away from the equator its relative vorticity changes to compensate the change in planetary vorticity. The result is an eastward jet downwind of the equator and strong upwelling on the upwind side (Cane, 1979; also see Philander and Pacanowski, 1981b). The multilevel model of Philander and Pacanowski (1979) allows the vertical structure of modes and currents to differ. They added the important result that the adjustment of the upper ocean is via the second baroclinic mode, the gravest mode which is very nearly trapped above the thermocline.

In Philander and Pacanowski (1981a) the response to perlodic winds was explored systematically. For periods shorter than 10 days there is little rectifled motion, but as the period approaches 50 days intense eastward surface currents can develop. For periods up to 150 days there is great variability above the main thermocline (though not below) and an intense undercurrent develops. For still longer periods the model ocean response is a succession of equillbrium states. (The numbers given are for a $5000 \mathrm{~km}$ basin and would increase linearly with basin size.) Katz and Garzol1 (1982) used these theoretical results to explain the observed seasonal variations of equatorial currents in the Atlantic. The most striking result is that most of the variation in transport is due to the reversal of the surface currents rather than an 1ncrease in undercurrent speed.

As is true for their linear counterparts, nonlinear models show current structure and amplitude to be highly dependent on vertical mixing processes. The calculation of Semtner and Holland (1980) provides an interesting example. It used a very low value for vertical eddy v1scosity and generated a great deal of horizontal mixing due to turbulent eddies. In fact, the eddy activity in this model appears to exceed what is observed in the real oceans while the value used for vertical viscosity appears to be much lower than observations suggest (e.g. Crawford and Osborn, 1981a). Pacanowski and Philander (1982) incorporated a more realistic, Richardson number dependent parameterization of vertical mixing. They found that the vertical circulation and mixing at the equator are so vigorous that surface heating is essential for maintaining the stratification on timescales of 100 days. Without this stratification a mixing model will wipe out the shear between the surface and the undercurrent. Schopf and Cane (1982) found a similar result in a model that explicitly parameterizes the physics of the surface layer. Our lack of understanding of vertical mixing processes remains a significant limitation on our ability to model the equatorial c1rculation.

\section{Coastal Currents}

The Somali Current has long held a particular fascination for those who work in equatorial oceanography. The observations taken during FGGE have provided us with a clear description of the response of this current to the Southwest Monsoon (cf. Schott and Quadfasel, 1980,1982; Sintth and Codispoti, 1980; Brown, Bruce and Evans, 1980; Bruce, Quadfasel and Swallow, 1980; Bruce, Fieux and Gonella, 1982; Evans and Brown, 1981). The picture that emerges shows two anticyclonic gyres, one turning of fshore at about $10 \mathrm{~N}$ and the other at about $4 \mathrm{~N}$. The latter is observed to migrate northward beginning in the late summer, eventually coalescing with the more northerly gyre which remains approximately fixed in space. (This behavior is shown most clearly in the sequence of pictures of the thermal front at the northern edge of the gyres given in Brown, Bruce and Evans, 1980). Explanations for various aspects of the observed behavior have appeared in the literature, but there is no 
coherent synthesis as yet. The more northerly Eyre has been attributed to the local wind stress curl (which is unusually intense at this location; of. Wylle and Hinton, 1982 or Schott and Fernandez-Partagas, 1981). The calculations of Cox (1979) indicate that such a gyre will form in response to the northward strengthening of the longshore winds. Philander and Delacluse (1982) propose that the turn-off latitude of the southerly Byre is set by the interior flow: in response to a northerly wind an eastward jet will develop at about 4N (cf. Cane, 1979) and the western boundary current will adjust to supply the needed mass flux. Another possible (and somewhat similar) explanation is contained in the study of cross equatorial flows given by Anderson and Moore (1980). Nelther study explains the northward migration of this feature. However, Cox (1979) was able to simulate such behavior in a numerical experiment in which the wind along the coast was relaxed.

Philander and Delacluse (1982) contrasted the behavior at the western boundary in response to southerly winds (viz. the Somali Current) with that at an eastern boundary. At both boundarles the surface flow is in the direction of the wind, but at the eastern side the sea surface sets up so that the pressure gradient opposes the wind stress, driving a poleward undercurrent (also see McCreary, 1981b and Philander and Yoon, 1982). This is clearly evident in observations taken of the coast of Peru (Brockmann et al, 1980; Brink, Halpern, and Smith, 1980). Theory implies that the eastern boundary is an extension of the equatorial waveguide, and that the reflection of a Kelvin wave incident on the boundary at the equator should be evident at all latitudes along the coast. The observational study of Enfield and Allen (1980) suggests that this indeed the case. Allen and Romea (1980) and Romea and Allen (1982) have considered the modification of the coastal response due to the presence of the continental shelf.

\section{Equatorial Waves and Deep Jets}

Given their central role in theoretical equatorial oceanography, it is natural that observationalists would seek evidence for the existence of equatorial waves in the data record. As an overall characterization of these efforts it may be said that a number of papers have made a strong case, but that no data set is complete enough to identify more than a very few of the characteristic signatures of such waves. An early effort is that of Heisberg, Horigan and Colin (1979), who present evidence for the existence of a mixed Rossby-gravity wave in the Atlantic. The most striking example is the Relvin wave event observed in the Pacific in 1980 (Knox and Halpern, 1982). A disturbance in sea level crossed the Pacific from the dateline to the Galapagos at a speed of $2.9 \mathrm{~m} / \mathrm{s}$ without dispersing. These characteristics imply that it should be identified as a packet of first baroclinic mode Kelvin waves. Most of the work on equatorial waves has ignored the effects of mean currents, but there are a few exceptions. Hallock (1980) and Welsberg (1980) attempted to account for mean flow influences in GATE data;
Philander (1979) and McPhaden and Knox (1979) did theoretical studies of the influence of an undercurrent-like mean flow on a shallow water system. There have been no studies which considered the influence of a current system with a complex vertical structure.

Among the interesting observations reported over the past four years are those of deep equatorial jets. Beneath the thermocline in all three tropical oceans there are equatorially confined currents with vertical scales of several hundred meters and speeds of several tens of $\mathrm{cm} / \mathrm{sec}$ down to depths of several thousand meters. (For examples in the Atlant1c see Horigan and Weisberg, 1981, or Weisberg and Horigan, 1981; for the Indian Ocean, Eriksen, 1980 or Luyten, 1982; for the Pacific, Leetmaa and Spain, 1981, or Eriksen, 1981). The data presently available is not sufficient to permit a conclusive characterization of the suite of equatorial motions, but a speculative picture is beginning to emerge. Equatorial waves exist at all frequencies: there, is no cutoff at a nonzero inertial frequency. It appears that the deeper motions exhibit spectral peaks at annual (Eriksen, 1981) and/or semiannual periods (Luyten and Roemmich, 1982), periods for which there is an obvious source. (At present, it is not clear how much of the deep motions are quasi-steady). There is also evidence, especially in the upper $500 \mathrm{~m}$ or so, for peaks at periods in the range from 16 to 30 days (e.g. Duing and Hallock, 1980). The most 11kely explanation is that these motions result from instabilities of the mean currents (Philander, 1978; Cox, 1980). It is possible that some smooth spectral form will characterize motions at shorter periods, but it is also likely that significant peaks related to peaks in the winds will appear (Garzoll and Katz, 1981).

It would be a helpful simplification if the deep jets could all be described as a sum of Just a few types of wave motions; e.g. Kelvin waves, mixed Rossby-gravity waves and the gravest Rossby waves. Eriksen's analyses $(1980,1981)$ Indicate that this is not the case: the observations can only be described by a sum over many wave types.

\section{Sea Surface Temperature Variability}

The equilibrium temperature at the tropical sea surface is determined by a complicated interaction between solar radiation, infrared radiation and evaporation and is basically determined by atmospheric processes (Sarachik, 1978). There are now only three ways to shance SST at a point: by changing the vertical heat flux into into the ocean across the sea surface by purely atmospheric processes; by changing advection of heat into that point by a variety of purely oceanic processes; and by increases in mized layer depth (on an ocean whose temperature decreases with depth) forced by increased wind stirring. A fundamental distinction among these three methods of changing SST is that in the first method vertical heat fluxes through the sea surface cause the SST change while in the second and third method, all else beling equal, the SST change is dynamically caused in such a way that the vertical heat fluxes through 
the surface tend to restore the equilibrium and therefore oppose the SST change. Sometimes all things are not equal - positive feedbacks can arise, for example, in eastern oceans when cooling of the SST by ocean dynamics leads to stratus cloud formation by advective atmospheric processes thereby reducing the solar radiation reaching the surface and reducing rather than increasing the vertical heat flux into the ocean. All three methods of changing SST act in various places in equatorial oceans. We will discuss the observations of SST changes and the status of the models recently developed to address the processes that change SST.

In the central Indian Ocean, where temperature gradients are weak, advective temperature changes are small and SST changes are caused almost entirely by heat fluxes through the sea surface: simple one dimensional mixed layer models driven by fluxes of heat and momentum at the surface seem adequate for describing SST variability on time scales up to the annual (McPhaden, 1982). In the central Pacific, Stevenson and Niller (1982) find that two-thirds of the heat storage in the mixed layer can be explained by heat fluxes through the sea surface, the remaining third presumably accountd for by advective affects. The eastern Pacific exhibits a large and complex annual cycle with cold water appearing in northern summer and propagating westward with time (Horel, 1982). Niller 1ndicates that 608 of the variance of storage in a very large area (encompassing that part of the Pacific showing large annual variation, $6 \mathrm{~N}-6 \mathrm{~s}, 76 \mathrm{~W}-140 \mathrm{~W}$ ) can be accounted for by vertical heat fluxes through the surface although finer spatial scale budgets have not yeat been made. In the eastern Atlantic, the annual signal is dominated by a cold summer tongue of water that seems dynamical in origin in that the coldest SST's appear at times of smallest heat content (1.e. shallowest thermocline) and are marked by increases of the heat flux into the cold tongue (Merle, 1980).

A numerical model that has the capacity to deal with all three types of SST change must have enough vertical resolution to resolve the mixed layer, adequate dynamics so as to be able to model the wave, advective, and diffusive processes that affect SST, and an adequate enough representation of the atmosphere so as to get reasonable heat fluxes through the sea surface. One layer models, which may work well at simulating thermocline depth changes, are totally inappropriate for simulating SST changes, except in those places and on those time scales where thermocline variability is a suitable proxy for SST variability.

Philander has been using sixteen layer general circulation type ocean model forced by wind stresses, but not heat fluxes, at the sea surface (Philander and Pacanowski 1980, 1981). While carrying no explioit mixed layer, the non-uniform vertical resolution is chosen to be finest near the surface and since there are no surface heat fluxes, temperature changes are dynamically determined. In a study of reponse to meridional wind variations, Philander and Pacanowski, 1981, find patterns of SST distribution remarkably like those in the eastern Atlantic where SST is believed to be dynamically determined. In an investigation concentrating on improving the temperature structure in this model, Pacanowski and Philander (1981), find that a Richardson number dependent vertical mixing of momentum, and a vertical heat flux into the ocean are both necessary factors in obtaining realistic thermocline temperatures.

A recent numerical model by Schopf and Cane (1982) has explicitly coupled a mixed layer to a low vertical resolution dynamical model. Th1s model effectively replaces the directly wind driven, but fixed depth, upper layer in the model of Cane (1979) with a thermally active and variable depth mixed layer: it therefore constitutes the simplest wodel that not only contains enough dynamics to simulate the equatorial undercurrent but also has all the basic mechanisms (albelt in simplifled form) that affect SST variability. Initial tests with this model indicate a strong assymmetry between upwelling and downwelling: upwelling lowers SST directly by vertical advection while downelling leads to no direct SST change but does make it possible for SST to slowly change by entrainment at the base of the mixed layer. This assymmetry clearly Indicates that on short time scales there need be no relation between thermocline variability and SST variability. Further experiments with the model (Schopf and Harrison, 1982) indicate that the existence of SST signatures associated with downwelling Kelvin signals are advectively produced, and are therefore very much a function of the pre-existing mean state of the ocean. For some mean wind cond1tions, they showed that a downwelling Kelvin wave was able to induce SST changes similar in amplitude and form to the initial coastal and equatorial warming occurring during El Nino episodes in the Pactfic. While these initial results are encouraging, defictencies in the parameterization of vertical surface heat fluxes, taken proportional to the difference of SST and a fixed atmospheric temperature, are clearly apparent.

As thermally active equatorial ocean models begin to be developed, it appears as though the most difficult issue remaining to be addressed is that of the surface boundary condition for vertical heat fluxes. The heat flux into the ocean is influenced in an essential way by advective and convective processes in the atmosphere which are in turn influenced by sea surface temperature. The usual type of boundary condition that parameterizes heat flux by the difference between some fixed atmospheric temperature and the calculated SST is inadequate in that it takes no account of the role of the ocean in determining the atmospheric temperature. Perhaps a correct surface condition can only be applied by coupling a full atmospheric model to the ocean. In any case, it appears that progress in modelling SST variations may require a deeper appreciation by oceanographers of the nature of the interaction between the ocean and the atmosphere.

\section{The El Mino - Southern Oscillation Phenomenon}

The Southern Oscillation is an oscillation of surface pressure primarily between the broad low pressure area over the "maritime continent" 
centered on Indonesia and the center of the South Pacific high in the southeast Pacific, but also with global manifestations. A convenient Index of the $S O$ is the anomalous pressure difference (seasonal cycle removed) between the Southern Paciflc high and the Indonesian low. It is known that this index, the SOI, oscillates irregularly with periods roughly from 3 to 5 years and that periods of lowest sor coincide with anomalously warm water across the equatorial Pacific from the coast of South America to beyond the dateline, a distance comprising of more than a quarter of the circumference of the earth. This phenomenon of the interannual variation of Pacific SST, the anomalies beginning at the coast of Peru in phase with the normal seasonally warm water in March but then propagating westward into the open Pacific, is called El Nino. Because the causal relationship between the pressure fluctuations of the SO and the warm water anomalies of El Nino remains unclear, we will sometimes lump both phenomena together into a single acronym, ENSO.

While scenarios for ENSO due to Bjerknes and Wyrtk1 have been in existence for many years, the lack of data over vast regions of the Paciflc have required so much averaging over space and time in order to obtain smooth results, that spatial and temporal relationships have become obscured. While still plagued by a sparsity of data, Rasmussen and Carpenter (1982) assembled new SST and wind sets and composited the data for s1x El N1no perłods, those of 1951 . 1953, 1957, 1965, 1969 and 1972. Because the sequence of events for each individual El Nino was so tightly coupled to the seasonal cycle, it was found possible to composite the data by months during the EI Nino years but even here, data sparsity first required that 3 month averages be taken. This paper gives the first detalled description of the sequence of events in the ENSO phenomenon over the entire tropical Pacific basin and therefore is a major milestone on our road to understanding it.

We may summarize their description of the composite El Nino as follows. As early as the May of the year preceding El Nino, the South Paciflc high begins its anomalous weakening and, since the low pressure region over Indonesia exhibits no anomally until several months later, the weakening of the SOI is initially affected only by the South Pacifle high. By September of the year preceeding El Nino, the most striking anomalies seem to be connected to the South Pacific high with slightly warmer SST everywhere South of $20 \mathrm{~S}$ (the analyzed region extends only to $30 \mathrm{~S})$, anomalously warm SST and anomalous convergence to the south of the normal position of the South Pacific convergence zone (SPCZ), and some weak indication of anomalously strong equatorial easterlies to the west of the dateline. Thus, in this antecedent September, it appears as if the SPCZ, that convergence zone extending from Indonesia southeastward across the Pacific, has moved anomalously far south. By contrast, in the antecedent December, the SPCZ has moved anomalously far north, warm SST anomalies remaining everywhere south of $20 \mathrm{~S}$ accompanied by anomalous westerlies, but now a warm anomally has appeared on the equator at the dateline with indications of slight anomalous westerlies in this warm patch. On the coast of Peru, warm anomalies are still small but have begun to grow. By the April of the El Nino year, the anomalies are large at Peru (in phase wth the normal seasonal cycle), warm water has propagated westward halfway across the Pacific, and the warm patch on the dateline seems to have expanded eastward. In this April of the EN year, the SPCZ is anomalously far north, the ITCZ moves southward onto the equator to lie over warm water, and positive precipitation anomalies and westerly wind anomalies appear over the equatorial warm water. By September of the EN year, the warm dateline anomaly and the westward propagative warm anomaly have merged to give warm SST anomalies across the entire equatorial Pacific all the way to Indonesta. There are now very large westerly anomalies in the wind all across the Pacific but strongest in the western Pacific west of 160W. The SPCZ has stayed far north, the ITCZ has stayed far south and they meet roughly at the dateline rather than near Indonesia. Precipitation shows large increases near the dateline with decreases over Indonesia, all indicating that the vast thermal heat source, that would usually be over the maritime continent centered about Indonesia has moved eastward to the dateline. By January of the year following El Nino, these trends have reached their peak and a return to normal is Indicated by anomalously cold water everywhere to the south of $20 \mathrm{~s}$. Cold anomalies then appear at the coast of Peru and begin propagating westward along the equator, and the EI Nino cycle has come to a close.

The scenario presented is indeed complicated and we have gone into it in some detail because at our present level of understanding, it is not clear which parts are essential and which are not. Wyrtk1 $(1975,1979,1982)$ has offered hypotheses as to which elements are essential to El Nino. He notes that in the year preceding an El Nino event the easterlies over the Pacific are anomolously strong, raising sea level in the western Pacific and lowering it in the east (see especially Hyrtki, 1979). He proposes that the weakening of these winds generates downwelling equatorial Kelvin waves that propagate to the coast of South America and depress the thermocline there. Enfield (1981c) shows that during the 1972 El Nino the thermocline of Peru was normal in November-December 1971, but had lowered substantially by February-March 1972. In the 1975 paper Wyrtki indicates that the weakening of the winds in the central Pacific is the critical initiator of these events. However, the data presented by Rasmussen and Carpenter makes it clear that the winds in this region do not relax until after the warning at the coast has already begun to spread westward. Busalacchi and O'Brien (1981), in the simulation using real winds referred to earlier, identified the relaxation of the winds weat of the dateline as the precursor to the coastal warming and suggested that the subsequent collapse of the easterlies in the central Pacific helps maintain the deep thermocline at the coast throughout the El Nino year.

In summary, Wyrtki (1982) vlews El Nino as a vast sea-saw. The ocean is preconditioned by the stronger, high SOI easterlies, causing warm 
water to pile up in the west. Their subsequent relaxation generates Kelvin waves that carry the water back to the east. Wyrtki regards the preconditioning as essential; this is a bit puzzeling because according to theory the ocean dynamies should respond to the any changes in the winds.

There are as yet no theories that account for the entire sequence of events that comprise ENSO. It is generally felt that only the ocean has inherent timescales long enough to account for the four year quasi-periodiclty of the cycle. McCreary (1982) has constructed the first model to make this idea concrete. It produces a periodic ENSO signal with the period set by the cross Pacific travel times of an eastward Kelvin wave plus a westward higher order Rossby wave. In its present form the model does not account for the vartable spacing of El Nino occurrences or the apparent relation of El Nino to the seasonal cycle, but its most serious shortcoming is the schematic nature of the atmospheric component and its unrealistic response to changes in the model ocean.

That the lock1ng of ENSO to the seasonal cycle may be a clue to the entire sequence of ENSO was suggested by Ph1lander (1983). Based on a complete documentation of the seasonal cycle of SST and winds over the Pacific by Horel (1982), Ph1lander argues that the warm water that normally appears near Peru early in the year is particularly susceptible to positive feedback due to air-sea interactions. He argues that a warm anomaly off Peru produces enhanced westerlies at the western edge of the westward propagating normal seasonal warming which in turn enhances the warm water. While this is an argument, rather than a model, it contains the intriguing suggestion that it is El Nino that causes the so rather than the other way around.

As we see 1t, the current situation is as follows. There is an indication that the BN response is in the winds (Busalacchi and O'Brien, 1981) and that the precursors to the Peruvian warm water is the relaxation of the easterlies west of the dateline. Further, this relaxation is connected to the appearance of a pool of warm water near the dateline (Rasmussen and Carpenter, 1982), but no one has yet explained where this pool of warm water came from, or why so much of the antecedent warm anomalles appear south of $20 \mathrm{~S}$ or why the South Pacific High starts weakening. The ability to continuously monitor SST and winds over the entire South Pacific, presumably by satellite, seems a prerequisite to answering these questions.

\section{Surface Winds}

Since the equatorial thermocline and the equatorial currents respond primarily to changes In the surface wind stress, and since SST variability can additionally depend on the heat flux into the ocean which in turn depends in an essential way on the surface wind, it is clear that in order to understand the forced response we must know the surface winds to some degree of accuracy. Ideally, we would like to know the winds to an accuracy such that errors in the wind fleld would force errors in the response no larger than the measurement errors. Even when this accuracy can not be obtalned, useful results are still assured if the errors in the wind fleld force errors in the response small compared to the amplitude of the response. The required accuracy of the wind field varies from problem to problem and has not as yet been quantified - an obvious way to do this would be by series of numerical stmulations.

Currently, surface winds over the ocean are routinely collected only by selected 1sland stations, by ships of opportunity, and by satellite measurements of the motion of low level clouds and interpolating down to the surface. All of these methods suffer from Inherent inaccuracies and from spatial inhomogenieties that render it impractical to construct a basin-wide surface wind field by any single technique. On rare occasions, enough research platforms are placed in the ocean to enable the construction of a limited area surface wind field directly from measurements; this was accomplished during the GATE experiment, for example Krishnamurti and Rrishnamurt1, 1980.

Ship of opportunity measurements of the surface wind have been archived for over sixty years and this makes it possible to construct climatological monthly wind flelds over entire ocean basins (e.g. Hastenrath and Lamb, 1979; Hellerman, 1980) but even here, coverage is adequate only in limited regions. Since the quality of the individual wind measurements that go into the climatological average is not high, errors rapidly accumulate in those regions where ships rarely venture. Furthermore, the representativeness of the monthiy wind field depends on the degree of interannual variability present in the wind field and on possible high frequency allasing (Harrison and Luther, 1982). Only recently has any attempt been made to est1mate the errors inherent in the construction of climatological monthly wind fields (Hellerman, 1982).

The situation with respect to the construction of actual, rather than climatological, surface wind fields is still more unsatisfactory since the number of data avallable during any particular month is very limited. Subjective analysis by meteorologists trained to recognize wind patterns has been used (Goldenberg and o'Brien, 1981) to spatially interpolate the monthly Pacific ship wind fleld onto a regular grid for the years 1961-1970 but the quality of the resultant wind fleld remains unknown. cloud winds have been show to give reasonable time averaged surface winds (Halpern, 1979) in some regions but seem to fail in others (Garzoli, et al., 1982). Perhaps the best that can be done at the monent is to use all the sources of surface winds real-time assimilated into numerical weather forecast models which are then corrected afterwards when additional data, too late to have been included in the real time assimilations, become available. This method is still limited by the relatively small amount of data available and by their spatial inhomogeneity but would improve slowly as the forecast models improve. Lacking detailed comparisons with in situ measurements, it is at present impossible to assess the accuracy that even this best method can provide. 
The capability for almost synoptic surface wind measurements that satellite instruments could provide, especially the scatterometer (see the papers in Gower, 1981 and the Vol. 87, April 30,1982 issue of J. Geophys. Res.) is an excitIng possibility for the future. A basin-wide surface wind fleld of known accuracy would be a major boon to equatorial oceanographers.

\section{Summary and Outlook}

The previous four years have seen notable progress in the use of simple shallow water models for describing the response of the thermocline (and, by proxy, sea level) to the forcIng by large scale wind stresses (e.g. Busalacch1 and O'Brien, 1980, 1981). We noted that these models are not adequate to describe equatorial currents because the averaging above the thermocline is too severe to allow the appropriate non-linearities to develop. A simple division of the homogeneous layer above the thermocline into two levels, one communicating directly with the wind stress and one responding to the pressure changes induced by thermocline tilt, provides a model that describes much of the variability of both thermocline and currents in equatorial regions. We are aware of no case where upper ocean current variations described by such a simple model disagree qualitatively with those simulated by ocean general circulation models containing many levels in the vertical.

These simple models are clearly inapplicable to the description of the complicated motions observed below the thermocline. If these deep motions are forced from the surface, a crucial issue that needs to be addressed is the rate of energy leakage through the thermocline down Into the deeper ocean. Current est1mates are that dissipation rates below the thermocline are small, implying that the energy flux through the thermocline is also small. Hence most of the energetic motion forced at the surface is trapped above the thermocline. This leads us to belleve that we can model the essential features of upper ocean variability without considering the coupling to the deeper ocean below. Just why this is so is not altogether clear. There has been some work related to this issue by Philander (1978) and MoCreary (see McCreary, Moore and Plcaut, 1982), but muek remains to be done on the influence of variable stratification and realistic dissipation. The effects of mean currents, notably the equatorial undercurrent and the vigorous meridional circulation associated with 1t, on the vertical propagation of waves has not yet been considered. Additional questions remain about the degree of realism needed in modeling the stratification in and above the thermocline. Preliminary results already indicate that the description of sea level variability requires more than a single baroclinic mode and that the thickness of the thermocline itself undergoes varlations on seasonal time scales. Mocreary $(1981 a, b$,$) has long emphasized the need to con-$ sider high order modes in order to model the vertical structure of the current system. As more ocean data are collected, and as climato- logical data undergo more detailed and searching analyses, we expect that these models containing a single homogeneous layer above a delta function themocline will no longer prove adequate and that models with more resolution in the vertical will have to be invoked.

In emphasizing purely equatorial processes, we have not given enough attention to some basic larger scale questions which we expect to begin to he addressed during the next four years. In particular the entire question of the connection of equatorial circulations with the gyre scale circulation of the major ocean basins remains obscure. Sub-categories of this question involve the relation of the eastern boundary currents to the equatorial currentcountercurrent system, the role of upwelling in eastern boundary current dynamics and thermodynamics, and the sources of water and salinity for each component of the equatorial currentcountercurrent system and the eastern and western boundary currents that connect to them. In addition, some very basic descriptive equatorial oceanography still remains to be dono. For example, we still lack a climatology of the South Equatorial Countercurrent and of the subsurface countercurrents and the seasonal variations of most components of the equatorial current-contercurrent system still remains to be described in all three oceans.

During the next four years, we expect much emphasis on theoretical investigations of the mechanisms responsible for SST variability, and on field investigations of SST variability on annual and interannual time scales. A variety of models will be developed, both linear and non-linear, having increased resolution in the vertical and containing thermodynamically active upper levels. He expect to see these models used for simulations of not only thermocline depth and structure and the associated currents, but also of the concomitent SST variations.

Many new data sets will become available from ongoing and planned fleld programs in the equatorial oceans: EPOCS (Equatorial Pacific Ocean Climate Studies) in the eastern Pacific; Tropic Heat in the central Pac1fic; SEQOAL (Seasonal Equatorial Atlantic Experiment) and FOCAL (French Ocean Climate Atlantio Experiment) in the atlantic. He expect a continuing and deepening interest in the problem of the EI Nino phenomenon theough the ENSO (EI N1no - Southern Oscillation) program and the EI Nino Rapid Response experiment, both under the overall aegis of TOGA (Tropical Ocean - Global Atmosphere). We expect that satellite remote sensing and telemetry will play an increasingly important role in the execution and design of these and future field programs.

Finally, we expect oceanographers to become more and more interested in the general role of the ocean In climate and increasingly aware of the problems of heat transport in the oceans. This will require additional study of the general nature of couplings at the air-sea interface and the partioular question of how to parameterize vertical heat fluxes through the ocean surface. As our capacity to make measurements in the equatorial oceans increases, the requirement for more accurate surface winds becomes more pressing. 
We close by noting that the three major oceans differ in size, geography, and wind forcing. It will be through the comparative study of equatorlal processes in all three oceans that our understanding of equatorial oceanography wll be most profoundly increased.
Acknomledgements: This work was supported by NASA Grant NGR 22-009-727 and NSF Grant OCE7922046 at MIT and by NASA Grant NGL 22-007-22B at Harvard. We wish to thank Dr. D.E. Harrison for critically reading the paper and D.F. Franzosa for carefully preparing the manuscript.
Allen, J.S. and R.D. Romea, On coastal trapped waves at low latitudes in a stratified ocean. I. Fuld Meoh. , 28, 555-585, 1980.

anderson, D.L.T. and D.W. Moore, Crossrelevance to very remote for ofing of the Somal relevance to very remote for ofing of the
ourrent, Deep-Sea Res., 26A, 1-22, 1979.

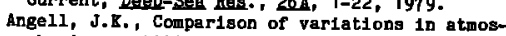
pheric quantities variations in the equatorial eastern Pacific. Hon. Yea. Rey., 109, 230-24J, 1981.

Bacastow, J. A., J, A. Adams, C.D. Keeling, D.J.

Moss, T.P. Whorf and C.S. Wong, Atnospherio carbon diozide, the Southern Oscillation, and the weak 1975 El N1no, Seitence, 210, 66-68, 1980 .

Barnett, T.P. and W.C. Patzert, Scales of thermal variability in the troplcal Paclfic, I. Phvs: Oceanorr. , 10, 529-540, 1980

arnett, T.P., Statistical prediction of North American air temperatures from Pacific predic tors, Yon. Hea. Rev., 109, 1021-1040, 1981.

ocoan/atmosphere fluotuations in the trop/oal Pacific, I. Phys. Deeanoors. , 11, 1043-1058, 1981 .

Behringer, D.W. and H. Stommel, Annual heat gain of the tropical Atiantic computed from subsurface oceen data, I. Phys. Qceanocr., II, 1393-1396, 1981.

Boyd, J.P., The nonlinear equatorial Kelvin wave, J. Phys. Deanosr., 10, 1-11, 1980. Boyd, J.P., Equatorlal solitary Waves. Part I: Rossby solitons, I. Phys. Desanorr., 10, 1699-1718, 1980

Boyd, J.P. and Z.D. Christidis, Low wavenumber Instability on the equator1el beta-plapo, feo Dhrs. Res. Let. , 9, 769-772, 1982

Brink, J.H.; D. Halpern and R.L. Smith, Circulat1on in the Peruvian upveli1ng system Near S, I. Geophys. Res., 85, 4036-4048, 1980.

Ink, R. H., A comparison of long coastal trapped wave theory with observetions of $f$

Prock, II. Phys. Oceanoar., 12, 897-913, 1982.

Smith, The rahrbaoh, A. Huyer and R.L. Peru coast: 5 to $15 \mathrm{~S}$, Deep-Ses Res., $27 \mathrm{~A}$. $847-856,1980$.

Brown, O.B., J.G. Bruce and R.H. Evans, Evolution of sea surface temperature in the Somal1 basin during the southwest monsoon of 1979 , scienca, 209, 595-597, 1980.

Brown, O.B., Observation of long period sea surface temperature variabillty during GATE, Equatortal and A-Sagle Deeanorraphy, Supp. II to Deep-Sea Fes., 26h, ed. W. Duing, Pergamon

Bruce, J.G., Eddies off the Somall coast during the southwest monsoon, J. Geaphys. Res., Bh

Bruee, J.G., D.R. QuadfaseI and J.C. Swallow, forwation during the commencement Res. $856654-6660,1980$,

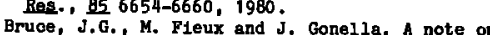
the cont. M. Fleux and J. Gonella, A note on cessation of the Soutbwest monsoon, Doeanolo

Floa Acta, 4, 7-9, 1982.
Bruce, J.G. and W.H. Beatty, III, observations

of the diurnal heating in the western equator1al Indian Ocean, Oceanologica Acta, 5.

137-139, 1982

Bryan, K.. Poleward heat transport by the ocean: Observations and models. Ann. Rey. Earth Planet. So1. 15-38, 1982.

Bunker, A.F., Trends of variables and energy Flures over the Atlant1c Ocean from 1948 to 1972, Mon. Hea. Rex., 108, 720-732, 1980.

variability of the tropical Pacific, I. Phrs Oceanozr. , 10, 1929-1952, 1980.

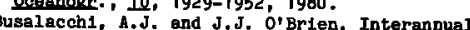
var1ability of the 1960 's, J. Geodhys. Res., 86, 10901-10907. 1961. Busalacch1, A.J. and J. Picaut, Seasonal varia-
bility from a model of the tropical Atlantic, I. Phys. Dasanoge. I 1962.

Cane, M.A., The response of an equatoriel ocean
to s1mple wind stress patterns: I. Model for- mulation and analytic resulta, I. Mar. Res.. 37, 233-252, 1979.

cane, M.A., The response of an equatorial ocean to simple wind stress patterns: II. Numerical results., ‥ Mar. Res.,37, 253-299, 1979.

Cane, M.A. and E.S. Sarach1k, Forced barociln1 ocean mot1ons, III: The linear equatorial basin case, J. Mar. Res., 37, 355-398, 1979. ne, M.A., On the dynamics of equatorial currents, w1 th application to the Indian
Ocoan, Deep-Sea Res., 27A, 525-544, 1980 Ocean, Deep-Sea Res., 27A, 525-544, 1980.
Cane, M. A. and D. H. Moore, A note on 10wfrequency equatorial basin modes, $\perp$. Phis. Prequency equatorial basin moded.

ane, M. A and $\mathrm{s}$, Sarachit The responee Ineer baroclinic equator lal ocean to of a forcing, I. Har. Res. 39, 651-693, 1981.

Cane, M. A. and Y. DuPenhoat, The ef rect of

lslands on low frequency equatorial motions, I. Mar. Res., 40 1981.

Cane, M.A. and R.J. Patton, A numerical model for low frequency equatorial dynamics, 1982. Cane, M.A. and R.J. Patton, Sources of cosstal upuelling in the Gulf of Gulnea, 1982.

Cane, M.A. and E.S. Sarach1k, Seasonal heat transport in a forced equatorial baroclinic model, s. Phvs. Oceanogr., 1983.

Diu, W-C. and A. L.O, A preliminary study of the possible statist1eal relationship between the the 107, 18-25, 1979 .

Chiu, H-C. Pulker, A study of the possible at, and D. relationship between the tropical Pacifio soa eurface temperture and ateoshar t1on, Mon. Hea. Rev and atmospheric oiroula-

Clarke, A.J. Hea. Rev., 109, 1013-1020, 1981.

coastal upwelling in the Gulf of Guinea,

Claophys. Res., B4., 3743-3751, 1979.

clarke, A.J., The reflection of equatorial waves from oceanic boundarles, submitted to $\perp$. Phys. Desanoes., 1982.

the C-s.A., Changes In the upper ocean within the C-scale array during Phase III, GATE-1 the B/C Soale, Supp. I to Deep-Sea Res. 26A, eds. G. Sledler and J.D. Woods, Pergamon Press, 115-127, 1980 .

Cochrane, J.D., F.J. Kelley, Jr., and C.R. olling, Subthermocline countercurrents in the western equatorial stlantic Ocean, I. Phrs. 0.eanorr. 9, 724-738, 1979.

Cox, H.D., i numerical study of Somall eurrent odd1es, 1 . Bhys. Dceanoge. . 2, 311-326, 1979. Cox, M.D., Generation and propagation of $30-d a y$
waves in a numerl cal model of the Pacific, Phys. Oasanngr. , 10, 1168-1186, 1980

Cox, M.D., A numerical study of surface cooling processes during summer in the Arabian Sea. I Monsoon Dynamica, eds. J. Lighthill \& R. P. Pearce, Cambridge Oniversity Press, 529-540,

Crewford, W.R., Pacific equatorial turbulence, Crawford, Plys. Oonowr. 12, 1137-1149, 1982.

w. R. Osborn, Microstructure easurent Corrent during GATE, Eoulatocial and A-Saale Ceeanogranhy, Supp. II to Deep-Sea Res., 26, 2 ,
ed. Halter Duing, Pergamon Press, 285-308,

Cravford, M.R. and T. R. Osborn, Energetics of the Atlantic equatorial undercurrent, Eovac torial and A-Scale Oceanographr, Supp. II to Press, 309-323, 1980.

Grawford, W.R. and T.R. Osborn, The control of equatorial oceen currents by turbulent dissipation, Satence, 212, 539-540, 1981

uing, $W$. and 2. Hallock, Equatorial uaves in the upper central Atlantic, GATE-2, Eavatoc1al and $1-$ Soale $\frac{0 \text { ceanorranhy, Supp. II to Deep-Sea }}{\text { Res. }}$. 6 , ed. W. Duing, Pergamon Press, Res. 26A, 26,

Duing, W., R. L. Molinari and J. C. Swallow,

Som W. R. L. Molinari and J. C. Suallow. Somell current: evolution of

Duing, U., and A. Lestmas, Arabian Sea cooling: A preliminary heat budget, I. Phys. Dceanoar..
Duing, U., F. Ostaporf and J. Merle, eds. Phvatcal Deaanography of the Trooical Atlantie Dur= 1980 .

Duing, W., ed., Eouatorial and A-Scale Dcennoge ranhy, Supp. II to Deep-Sea Res. ,26A, Pergamon Press, pp. 356, 1980.

Oakey, Average nicrostructure levels and vertical difrusion for Phase III, GATE, Ncannorraphy and Surface Laver Mateocoloory in the $B / c$ Scale, Supp. I to Deep-Sea Res., 26. eds. G. Sledler and

Woods, Pergamon Press, 273-294, 1980.
Egger, J., G. Meyers and P. B. Wright. Pressuro,

wind and cloudiness in P. B. Wright, Pressure related to the southern osoillation, Pon. Yes. related to the southern oso
Rer., 109, 1139-1149, 1981.

Anfiold, D.B. and J.S. Allen, on the structure anomalles along the Pacific const of Worth and South America, ㄴ. Phys. Oceanogs. I 10, 557 -

Enfield, D. B., Thermally driven uind varlability In the planetary boundary layer above L1ma, Prield, D. B. . . . 1ty of monthiy low-level wind flelds over the southeastern tropical Pacific, Mon. Her. Rey. 109, 2177-2190, 1981

Enfleld, D.B., EI Nino Psclfic eastern boundary response to 1nterannusl forclng, in Resomrae M. H. Glantz and J.D. Thompson, John WIley \& Sons, Ine., 213-254, 1981.

Eriksen, C.C., An equatorisi transect of the

Indian Ocean, I. Mar. Res., 37, 215-232, 1979.

trum of... Bvidence for a continuous specI. Feanhrs. Res. I 85, 3285-3303, 1980.

Eriksen, C.C., Deep currents and their interpretation as equatorial vaves in the vestern Pacific Ocean, I. Phys. Oaennoms. , 11, 4Q-70, 1981.

Eriksen, C.C., Bquatorial wave rertical modes observed in a western Paotfic 1sland array, $J$. Gaophrs. Beq. , 87, 1982.

Gricksen, C.C.. Geostrophic equatortal deep Jetc, I. Mar. Res. , 40, Suop, 143-157, 1982. Evans, R.H. and 0.B. Brown, Propagation of theral fronts in the Somal1 current syaten, Deen-Sea Res., 284. 521-527, 1981.

Fohn, H., Ocanic upwelling as a key for abrupt cl1wat1c change, I. Mat. Soe. Iapan, 60,

Garzol1, S. and E.J. Katz, Observations of Inertia-gravity waves in the At1antic from Inverted echo sounders during FGGE, ㄴ. Phys.
geseanoer. 11, 1463-1473, 1989.

Garzoli, S.L.. E.J. Ratz, H.-J, Panitz and P. Speth, In situ wind meesurements in the equatorial Atlantfe during 1979, Oceanolopiea lata, 5, 281-288, 1982.

Gent, P., Stand1ng equatorial wave modes in bounded ocean basins, J. Phrs. Oceanogr. 9 653-662, 1979.

Cent, P.R. and A.J. Semtner, Jr., Energy trapping near the equator in a numer1cal ocean

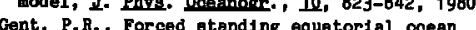

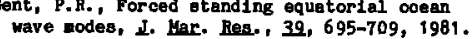
Gibbs, R.J., WInd-controlled coastal upwellins in the western Atlant1c, Deen-Saa Res., 27 , $857-866,1980$

Goldenberg, S.B., and J.J. O'Brien, Time and space variability of tropical Pec1f1e w1nd
stress, Mon. Hea. Rey., 109, 1190-1207, 1981.

Gower, J.F.R., ed., Deaanography from Snoae,

Plenum Press, pp. 978, 1981.

Green, E. and V.T. Buchwald, Inter1or shelf waves on an equatoriel - plane, I. Phrs.

0.eanexp. + 9, 1299-1304, 1979.

rose, P.L., Traneition in water mass propertien between 200 and 500 meters dopth in the GATE B-array, in geasnorraphy and Supface Laver Keteorology in the B/C Scale, Supp. I to Deep-Sea Res., 26A, eds. G. Siedler and J.D.

Hall oos, Pergamon Press, $147-160,1980$.

trapped waves in the presence of mean 
ourrents, In Eawatorial and A-Soale OcanosereDhy, Supp. II to Deep-Ses Res., 26A,
Duing, Pergamon Press, $261-284$, 1980 .

Hal pera, D.. Surface wind measurements and lowlevel cloud notion vectors near the intertropleal convergence zone in the central Pacific oceen from November 1977 to Karch 1978, Hon. Hea. Bev.: 107, 1524-1534, 1979.

Halpern, D., I Pacific equatorial teperature saction fros $172 \mathrm{E}$ to $110 \mathrm{~W}$ during uinter and spring 1979, Deep-Sea Rea., 27A, 931-940, 1980 .

Halpern, D., Var1ability or near-surface currents in the At1antic north equatorial countercurrent during GATE, I. Phrs. Deaan., $10,1213-1220,1980$.

Marrison, D.E. and D.S. Luther, Observing longperiod Pluctuations of surface winds in the Island date, submitted Mon. Hea. Rer., 1982. Island date, submitted Hon. Hea. ReY.. 1982. hastenrath, S, and P.J. Lamb, Crimatic At1as or the Indian Ooean, Part I: Surpace clinate ar Wisconsin Press, 1979.

Hastenrath, S. and P.J. Lamb, Climatio Atlas of the Indien Ocean - Part II: The oceanle heat budget, The University of H1acongin Press, 1979.

Hastenrath, S., Heat budget of tropical ocean and atmosphere, I. Phys. Depanogr., 10, 159170,1980 .

Hastenrath, S. and P.J. Lamb, On the heat budget of hydrosphere and atmosphere in the Indian Ocesn, I. Phys. Ocanarer. , 10, 694-708, 1980

Hayes, S.P. and H.B. Mill burn, On the vertical structure of velocity in the eastern equa635, 1980 .

Hayes, S.P. and C.J. Powell, Vertical wave aunber spectra of temperature fine structure 1n the Equatorial Pact

85. $4029-4035,1980$. tions in the eastern equatorial Pecific, I. Geoshys. Rea., 86, 10983-10999, 1981.

mass and transport variability at $100 \mathrm{w}$ in the

Hayea, S.P., A comparison of geostrophle and measured velocities in the Equatorial Onde current, 1. Mar. Bas., 40, Sube., 219-229,

1982. wind stress orer the tropical Atlantic, in Bountortal and A-Scale Daeasnogcaphy, Supp. II Prese, 63-75, 1980

Press, 63-75, 1980. the Dcennors. 1982.

Acannorg.' ' 1982 .

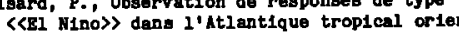
tal Golfe de Guinea, Deanolorias Acta, 3.

69-78, 1980 .

H1sard, P. and J. Merle, Onset of sumer surface cooling in the Gulf of Guinea during GATE, in Eauatorclal and A-Scele Oceanorrophy, Supp. II to Deep-Sea Res., 264, ed. W. Duing, Perganon Press, 325-341, 1980

Horel, J.D. and J.M. Wallece, Planetery-scale atmospherto phenonene associated with the Southern Oscillation, Kon. Mes. Rey. 109. 813-829, 1961.

On the annual oycle of the tropical Paciric a tmosphere end ocean, Hon. Has.

Rev. 1110, - 1982 .

origan, A.M. and R.H. Welsberg, A systenat1e searoh for trapped equatorial waves in the GATE volooity

Huyer, A., The offahore structure and subsurface expreseion of sea level variations of Peru,

Jacobs, C.A., Maan diurnal and shorter period varlations in the elr-see fluxes and related parmeters during GATE, Ocasnoornaphy and SurI toce Lever Heteorolory in the B/C Scale, Supp. I to Deep-Sea Res. $26 \mathrm{~A}$,

J.D. Woods, 65-85, 1980 .

Johnson, Donald R., M. Mutua Ngull and E.J. winds at the southern boundary of the Somal1 Current, Daep-Sea Res., 29, 1217-1228, 1982

Judkin, D.C.. Vertical distribution of zooplankton in relation to the oxygen minimu.

off Peru, Deep-Sea Res., 27,, 475-487, 1960
catz, E.J., and collaborators, zonal pressure gradient along the equator lel atlant1c, $\mathbf{I}$. Bax. Ren. , 35, 293-307, 1977.

Ketz, B.J., J.G. Bruce and B.D. Petrle, Selt and mass flux in the atlentic equatorial underourrent, in Eauatortal and A-Seale OcoanopraDhy, Supp. II to Deep

Katz, E. J., R.L. Mol1nar1, D.E. Cartwr1ght, P. H1ard, H. U. Lass, A. deleeguita, The geaHisard, H.U. Lass, A. dellesquita, The seasonal transport of the equatorlal undercus In the western Atlantio (during the global veather exper1

Katz, E.J., Dynamio topography of the sea sur- face in the equatorial Atlantic, I. Mar. Hes., 39, 53-63, 1981

Ratz, E.J. and S. Garzoll, Response of the western equatorial Atlantic ocean to an annual Hind 1982 .

Seshavernurty, R.ll. Response of the atmosphere to sea surface temperature anomalles over the equatorial Paciric and the teleconnections of the southern osc

1241-1259, 1982.
Indle, J.C., Equatorial Pacific ocean variab1lIty - seasonal and Bl Nino time scales, Ph.D. Issertation, Dept. of Oceanography, Florida State Oniversity, pp. 139, 1979.

nox, equatorial

Knox, R.A. and D. Helpern, Long range KeIvin wave propagation of transport variations in Pacific ocean equatorial currents,

Kraus, E. B. and B.P. Hanson, AIr-Sea Interaction as a propagator of equatorial ocean surface ceaperature anomalles, I. Phys. 0.eanors. 1982.

Krishnamurt1, T.N., and R. Krishnamurt1, Surface meteorology over the GATE A-scale, in Eavatoptal and A-Scale Deeanograohy, Supp II to Deep-Sea Res., 26A,

Lanb, P.J. and A.P. Bunker, The annual march of the heat budget of the north and tropical Atlontle Oceans, $\perp$. Phra. Oceanoer. I 1982.

Lass, H. D.. V. Bubnov, J.M. Huthnance, B.J. Catz, J. Halnke, A.dellesquita, F. Ostaporf and B. Volturez, Seasomal changes of the zomal pressure gradient in the equatorial Atlantic

during the FGEE year, Daeanolocica Acta, large-scale a1r-sea interact

Lau, '-H.Y., Oscillations in a siople equatorial clinate systen, I. Athos. Sal., 38, 248-261, 1981 .

Loetaaa, A. and H. Stomel, Bquatorial current observations in the vestern Indian ocean In 269,1980

Leetmae, A.. H.T. Rossby, P.M. Saunders and P. Nilson, Subsurface c1rculation 1n the
current, Sotence, 209, 590-592, 1980 .

current, Solence, 209, 590-592, 1980.
Leetana, A., J.P. HeCreary, Jr.; and D.W. Hoore, Equatorial currents; observations and theors, in Erolution of Phystcal Oceanography, eds B. A. Warren
Press, 1981.

Leetmaa, A. and P.F. Spa1n, Results from a velocity transect along the equator from 125 to 1981 . Leetmae, A., The role of loosl heatiog in pro-
duc1ng temperature variations in the eastern

tropical Pecific.
Leetuas, $A$, Observations of near-equatorial flows in the eastern Pacific, I. Mar. Her.. 40, Supp., 357-370, 1982.

eetraa, A., D. R. Quadfasel and D. Wisson, Developent of the flow fleld during the onset of the Sosall Current, 1979. I. Phrs. Deanoer., 1982

Lighthill, S1r Janes, and R.P. Pearce, Mnonsoon 1981 .

Lin, L.B., and H.E. Huriburt, Maxinum alnplif1cation of nonlinear Somall current dynamics, in Monsoon Drnanica, ods. J. Lighth1l1 and R55, Pearc,

Lukas, $R_{\text {., }}$ The terminstion of the equatorial undercurrent in the eastern Pacific, Ph.D. Thes1s, OnIrersity of Hava11, 127 pp., 1981. Luther, D.S.. Observations of long period waves in the tropical oceans and atwosphere, Ph.D. Thesis, Hase. 1980 .

pp., 1980.

Luyten, J.R., M. Flew and J. Gonella, Equa-
tortal eurrents in the western Indian Ocean, torlal eurrents in the weste

Satence, 209, 600-602, 1980 .
Luyten, J. R. Recent observations in the equator1al Indian Ocean, Hananon Drnan1ca, eds. J. LIghth1ll and R.P. Pearce, Cambridge Onivera1ty Press, 465-480, 1981.

buyten, J.R., Equatorial current measurements, 19-40, 1982 .

Luyten, J. R. and D. H. Roemmlch, Equatorial currents at ceml-annual period in the Indian

MoCreary, J., I linear stratifled ocean model of the equatorial undercurrent, Phill. Trans. of the equatorial undercurrent, Phill. Trans MeCreary, J.P., Jr., A linear stratified ocean corrent phil. Trans. of the Roy. Soe. of hen= conrent $385-413,19816$.

MoCreary, J.P., Jr., D.W. Moore and J.M.w1tte, Rent the Report of the Einal Heeting of SCOR Horking

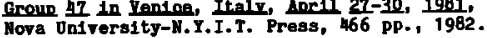

HeCreary, J.P., Jr., A model of tropleal oceanataosphere Interaction, Mon. Hee. Rey., 110, 1982

MoCreary, J.P., J. P1caut and D.W. Moore, Effeat of annual remote forcing in the eastern

McPhaden, J. and R.A. Inox, Equatorial Eelvin and 1nertio-gravity waves in zonal shear Plow., l. Phrs. Oenanorr. , 9, 263-277, 1979.

of the ateady-state equatorial ocean, 1. Phrs. of the steady-8tate equator1al
0oeanorr., 11, 337-354, 1981.

McPhaden, K.J., Variability in the central equatorlal Indian Ocoan - Part I: Oco
I. Mar. Res.. 40, 157-176, 1982 .

1. Mar. Res., 40, 157-176, 1982. Phaden, M.J., Variability in the oentral equa-
torial Indian Ocean, Part II: Ocoanic heat and turbulent energ balances, $\mathbf{I}$. Mar. Bes., 40 , 403-419, 1982.

MoPhaden, M.J. and A.J. Semtner, The effects of ween shear flow on equatorial basin

Phrs. Oceanors., 12, 795-804, 1982.
Meehl, G.A., Characterist1os of surfece current flor inferred from a global ocean current dat set. I. Phrs. Oceanocr.' 12, 538-555, 1982 .

Merle, J. and J.Le Floch, Cyole annuel moyen de la temperature dans les couches superieures de Acta, 1, 271-276, 1978.

Acta, 1, 271-276, 1978.
Merle, J., M. Fieux and P. Hisard, Annual Signal and interannual anomalles of sea surface temperature in the eastern equatorial Atlantic Ooean, Eaulatortal and A-Soele Oceanorraphr, Supp. II to Deep-Sea Res., 2 ,

Pergamon Press, 77-101, 1980 . interannuelle de l'ocean atlantique equatorial

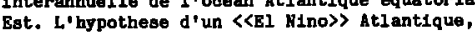
Oceanolopioa Aata, $3,209-220,1980 \mathrm{a}$.

Merle, J., Seasonal veriation of hest-storage in the tropical Atlantic Ooean, Ocoanolifetea Acta, 1980, 3, , 455-463, 1980 b.

Merle, J. Seasonal heat budget in the equatorial Atlantic Ocean, I. Phys. Oceanorrs., 10, 464 $469,1980 \mathrm{c}$.

Meyers, G., On the annuel Rossby wave in the tropical Morth Pac1f10 Ocean, I. Phys.

Meyers, G., Annual variation in the slope of the $14 \mathrm{C}$ 1sotherm along the Equator in the Peatf Ocean, J. Phrs. Oceanoer, 2, 885-891, 1979.

Meyers, G., Do Sverdrup transports account for the Pacific north equator 1al countercur
I. Geophrs. Res., B B5, 1073-1075, 1980.

Hoyers, G.. Interannual variation in sea lovel near Truk Island - A bimodal season

J. Phrs. Oceanoss.' 12 , 1982. variation in baroclinie structure of the nor thwestern tropical Pacific, easeanogr. trop.

1, 59-69, 1982 .
Mofjeld, H.0., Ef focts of vertical viscosity on
Kelvin waves., I. Phys. Donanors., 10, 1039Kelvin waves.

Mof jeld, H.0., An analytic theory on how friction affects free internal waves in the equatorial waveguide, I. Phys. Ocesmogr., 11.

1585-1590, 1981.
Molinar1, R., Satellite tracked drifting buoy observations of near surface currents and ten perature in the Centrel and Western tropicel 1982.

Mol Inar1, R.L., B. Vot turtez and P. Dunoen, Observations in the subtherwooline undercurrent of the equatorial south Atlantic oceen: 1978-1979, Doeanoletea Aeta, ㄴ, 451456,1981 .

Molianri, R.L., Observations of eastward currents is the troplcal South Atiantic Ooean: 1978-1980, L. Geophre. Bes., B7, 9707-9714,

Moura, A.D. and J. Shukla, On the dynamics of droughts in northeast Braz11: Observations, theory and numerical experinente with a general of roulation

Miller, P. and J. Sterenson, The beat budget of tropical ocean warm vater pools, $\mathbf{I}$. Mac- Res. ,

lof, D., On the dynamics of equatorial outflows Mar. Bes., 39, 1-29, 1981.

o'Brien, J.J., Equator1al Oceanography, Rey. of 'Brien, J.J., Equatorial 0ceanography, Rey.
Geoghys. and Spees Dhrstas, 17, 1569-1575,
1979.

O'Brien, J.J., A. Busaleceht and J. Rindle, Ooean models of EI NIno, Rescources Manarement and Rnyironmental Incert.sinty, ed. M. H.

o' Kelll, R.., Observations of vertical propagatIng oquatorially-trapped weves in the deep vestern Indian Ocean, Ph.D. Thesis, Johns

kins University, pp. 161, 1982,
Osborn, T.R., and L.E. Bilodeau, Temperature lerostructure in the equatorial Atlantic, I. Phye. Oceanogr. 10, 66-82, 1980.

Ostaporf, F.. More on the zonal preseure gredients in the equatorial Atlant1c, oceanolo-
c10a Acta, 5, 265-276, 1982 .

Pacanowskl, R.C. and S.G.H. Philander, Parame- 
terization of vertical miring in nuwerical models of tropical oceans, I. Phrs. Dreanogr. 11, 1443-1451, 1981.

Pazan, S.E., and G. Meyers, Interannual fluctuations of the tropical Pacific wind field and the southern oscillation, Man. Hea. Rey. 110, $587-600,1982$

Perkins, ,., Low-frequency forcing of the tropscal atlentic ocean under ITCZ during GATE, in Ocasnogranhy and Surface Laver Meteocolong in the B/C Soale, Supp. I to Deep-Sea Res., 26h, 225-236, 1980 .

Philander, S.G.H. Instab1lities of equatorial zonal currents II, I Genohrs. Pes. 83. 3679-3682, 1978.

Phil ander, S.G. G., Nonlinear cosetal and equator1el Jets, I. Ehrs. Leasnews., 2, 739-747, 1979.

Philander, S.G.H., Upwelling in the Gulf of Guinee, I. Mar. Bes., 37, 23-33, 1979 .

Philander, S.G.H., Equatorial weves in the presence of the equatorial undercurrent, I. Phrs. Doeanoar. o 2, 254-262, 1979.

allander, S.G.H., Varlability of the tropical oceans, Drn. of Atmes. and oceans, 3, 191-208, 1979.

Shlander S.G.H., and R.C. Pacanowak1, The genoration of equator1al curr

Philander, G. and Walter Duing, The coeanic circulation of the tropical Atlantic and 1ts variability, as observed during GATB, in Rovatortal and i-Scale 0oesnoprenhy, Supp. II to Deep-Sea Res., 26h, ed. Walter Duing, Pergamon Dreas, 1-27, 1980

Philender, S.a.H., The oquatoriel undercurrent rovisited, Ann. Rer. Earth Planat. Sci., B, 191-204, 1980 .

Philander S.G.H., The response of equatorial oceans to a relexation of the trade yinds, $\mathbf{J}$. of Phys. Ooeanoss. I 11, 176-189, 1981 .

hil ander, S.G.H. and R.C. Paoanowsk1, The oceante response to eross-equatorial winds (with application to coastal upwelling in
tudes), Tellua, $33,201-210,1981$.

Philander, S.G.H. and R.C. Pacanoviki, Responee of equatorial oceans to periodic forolng, It

Beaching. Res., 86, 1903-1916, 1981.

derder, S.G.H., and J.-H. Yoon, Bastern boundary currents and cosstal up

$P b 1 l$ ander, S.G.H., and P. Dolecluse, Cosstal currents In low latitudes (w1th application to the SomalI and EI Hino ourrents), Deep Sen Res.., to appear, 1962

phllandor, S.G.H., E1 Wino - Southern 0sc1llation phenomens, Nature 1983

Preller, R. and J.J. O'Brien, The Influence of bottom topography on upwelling off Peru, I. Phys. Doeanose. , 10, 1377-1398, 1980

Quadfasel, D.R., Low Prequency var1ability of the 20 c c lsotherm topography in the vestern equatorial Indian

Quadfasel, D. . and $F$. Sohott, Yater-mase distributions at 1nternediate layers ofr the Somall coase during the onset of the the monsoon, 1979, I phys onset of the sout

monsoon, 1979 , s. Phrs. Ooannorx.', 1962. The central Pacifio near-equatortal conver gence zone, I. Faoohys Res., B6, 6580-6598, 1981.

Ranage, C.S. and A.M. Hor 1, Mateorol ogical aspeote of EI N100, Hon- Hes. Ber., 109 $1827-1835,1981$

lasmusson, B.M. and T.H. Carpenter, Variations In tropical sea surface temperature and surface wind flelds assoolated with the southe osolllation/E1

Fasmusson, E.M.; and T.H. Carpenter, The relettonship B.M., and T.K. Carpontor, The relationship between eastorn oquatoral Pacip1o rainfall over India, May, 1982.

Reed, R.J. and R.M. Lew1s, Response of upper ocesn teaperatures to diurnal and synopticscale variations of teorological paraneters in the GATE B-Scale srea, Deaanorranhy and Sucfane Laver Mateorolory in the B/C Scale, J.D. Hoods, Pergamon Press, 99-114, 1982

R1pa, P. and S.P. Hayes, Evidence for equatorie trapped veves at the Galapagos Islands, I. Geophys. Res., B6, 6509-6516, 1981

Ripa, P., Nonlipear wave-wave interactions in a one-layer reduced-gravity model of the equa-
$111,1982$.

Ripa, P., Resonant Interactions of equatorial waves in a one layer model $r$. Hon Iocal triads and triads of waves with the sane

Ripa, P., Resonant Interactions of equatorial waves in a one layer model II. General clas alfication of

triads, 1982.

Bloman transports in the tropical Atlantic, I. Ncman transports in the

Romea, R.D., and J.s. Ailen, On forced coastal trapped waves at lor latitudes in a gtratified ocean, J. Mar. Rose, 40, 369-401, 1982

Rowea, R.D., and J.S. 'Mlen, on verticaliy propagating cosatal relvin vaves at 10 latitudes, I. Phys. Depanorc. submitted, 1982. Saracbik, B.S.. Troplcal sea-aurface tempar ture: An Interactive one-dimensional atnosphere-ocean mode1, Den. Atros. and 00e-
ans, 2, 455,469, 1978.

Sledler, G. and J.D. Woods, eds., Oceanoeranhy and Surface Laver Hateorolong in the $B / C$ roale, Supp. I to Deep - Pees

Sohopf. P.S., The role of Elman flow and planethe $341,1980$.

Schopf, P.S., D.L.T. Anderson and R. Sm1th, Beta-diapersion of low-frequency Rossby Haves, Dyn. of Atmos. and 0ceans, 5, 187-214, 1981. schopp, P.S. and M.A. Cane, On equatorial dynaeles, wixed layer physics and sea surface teaperature, I. Phrs. Ocasanogr. subnitted, 1982

Schopf, P.S. and D.E. Harrison, On equatorial Kelvin waves and BI Mino:

ple mean wind flelds, 1982 . Development of

the subsurface currents of the northorn Scal1 ourrent gyre from March to July 1979, Satence. 209, 593-595, 1980 .

schott, F. and J. Ferzandez-Partagas, The onset of the sumar monsoon during the FGE 1979 exporinent pars, J. Geophra. Res.. B6, 4173-4180, 1981.

Sohott, J. Gaophra. Res... B6, 4173-4180, 1981 fluetuations off Somalla during the 1979 susner monsoons, 1 Phys Oceanoer. 1982.

mor monsoons, l. Phys. Oceanogr., 1982. the Somall eurrent systen during the onset of the southwest monsoon, 1979. I. Phys.

Deanows., 1982.

Semtner, A.J.. Jr., and H.R. Hol land, Huaerical simulation of equatorial ocean ol reulation. Part I: A bas1c case 1n turbulent equil1brium, I. Phys. Dasanors. , 10, 667-693, 1980 Schaffer, G., On the upwelling circulation over
the wide shelf off Peru: 1. C1rculation, I. ther. Res., 40 293-314, 1982.

Sarith, S.L. and L.A. Cod19poti, Southwest monSaith, S.L. and L.A. Codispot1, Southwest
soon of 1979: Chemical and biological response of Somal1 coastal waters, Sc1ence, $209,597-600,1980$

Stevenson, J.P. and P. Willer, Tropical heat flux and storage during the FGGE shuttle experinent. 1982.

Swallow, J.C., Observations of the Somall current and 1 ts relationship to the monsoon winds, Hoontoon Drnantes, ods. J. Lighth111 and R.P. Pearce, Cambridge University Press, 444-452, 1981.

Toole, J.M., Anomal ous charaoteristica of equatorial thermobaline finestructure, I. Phrs Doeanors., 11, 871-876, 1981

suchiya, M., Seasonal variation of the equaor1el zonal geopotential gradient in the eagtern Pacific Ocean, 1 . Mac. Res., $37,399-$
407, 1979. $407,1979$.

rouchlya, H., The origin of the Paelfic oqua794-812, 1981 .

Verstraete $\mathrm{H}-\mathrm{M}_{*}, \mathrm{~J}$. Pleaut and $\mathrm{A}$. Morliere, Atmospherice and tidal obsevations along the shelf of the Guinea Gulf, Earatorial and LScale Onoanorraphy, Supp. II to Deep-Sea Res. 261, ed. M. Duing, Pergamon Press, 343-356, 1980

Walsh, J.J., R.w. Whitledge, U.E. Esatas, R.L. Saith, S.A. Huntsmans, H. Santander and B.R. De Mend10la, The spauning habitat of the Peruvian anchovy, Bo
27A, 1-27, 1980.

Weare, B.c., A stat1stical study of the relationships between ocean surface teaperaturea
2279-2292, 1979.

Neare, B.C.. P.T.Strub and M.D. Samuel, Annual mean surface heat fluxes in the tropical $717,1981$.

Neare, B.C. and P. Ted Strub, Annuel mean atmoepherle stat1st1es at the surface of the trop1-
cal Pacif1o ocean, Hon. Hea. Rey., 109, 10021012, 1981 .

Weare, B.C., E1 Mino and tropical Pacifio ocean surface teaperatures, I. Phrs. Ooesanerr., 12 , $17-27,1982$.

Weare, B.C. and J.S. Masstrom, Eramples or extended empirical orthogonal function ana-

Neisberg, H.H., A. Hor1gan and C. Colln, Equa-

torlally trapped Rosaby-grarity vave propaga$67-86,1979$.

Weisberg, R.H. and A.M. Horigan, Low-frequeney varlability in the equatorial Atient1c, I.

Phrs. Oceanoor., 11, 913-920, 1981.

Melsberg, R.H., Equatorial waves during GATE and their relation to the mean zonal elroulation, to Deep-Sea Res., 26A, ed. W. Duing, Perganon Prese, 179-198, 1982.

Welsberg, R.R., L. Miller, A. Horigan and J.A.

torial thermooline dur1ng GATE, Eovatorial and

A-Sesle Oceanorranhy, Supp. II to Deep-See Res., 261980 .

and R.E. Deanis, Verlability of tho upper ocoen mass flold in the oastern tropical Atlantic during GATE, Oneanograph and Sureane Layer Meterocology in the B/C Soale, Supp. I to Deep-Sea Res.., 26A, eds. G. Siedlex an 1980 .

146, 1980 . regions of the coesns: A blbliography

regions of the coesns: A b1bick
Nove/MYT Press, pp. 73, 1980

Wove/MIIT Press, pp. 73, 1980 .

arthea, A. and G. Mellor, Turbulance closuro Deaenomanhy and Surface Laver Meteoroloce in the $\mathrm{B} / \mathrm{C}$ Soale, Supp. I to Deep-Soe Res., $26 \mathrm{~A}$ Press, 237-272, 1980 .

Wr11e, D.P. and B.B. Hinton, Some statistical characteristios of cloud motion winds measured over the Indian ooean during the summer movsoon, Hon. Hea. Bey., 109, 1810-1812, 1981. Wylle, D.P. end B.B. E1nton, The foasibility of estimatiog larga-scale surface yind fielde for deta, Bound-Laver Met. $21,357-367,1981$.

Hylie, D.P., B.B. Hinton and K.M. Millett, $A$ comparison of three satellite based methods Apol. Yat. , 20, 438-449, 1981.

ApDl. Yat. 20, ' 438-449, 1981. wind atress

petterns over the Indian ooeane during the summer monsoon of 1979., l. Phrs. Oconnores. , 12, $186-199,1982$.

Wyrtki, K., E1 Wino - The dynamic reaponse of the equatorial Feciric ocean to atmosphertc forcing, $t$. Phye. Oosanogr.., 5, 572-584, phy to the 1976 BI N1no, I. Phtre. Deeanorre.

2, 1223-1231, 1979. Mollally, U.C. Patzert, E.D. Stroup, B.A. Taf and R. Hilliams, The Hawali to Tahit1 shut tle experiment, Scitence, 211, 22-28, 1981.

Wyrtk1, R., h estimate of equatorial upwelling in the Pacifie,

Wyrtk1, K., Eddies in the Pacifio north eque$749,1982$.

Wrtk1, $\mathrm{K}$, The southern osollletion, ocean-

atmosphere Interaction end El Hino, Mar. Teob. Soc.. .. 16, 3-10, 1982 .

Myrtki, $\mathrm{R}$. and G. Eidin, Equatorial upvelling events in the central Pacific, I. Phys.

Oceanorr. , 12, 984-988, 1982 .
Yoon, H-G., Effeots of 101 ands on equator 1 a waves, L. Geoshrs. Les., 86, 10913-10920,

1981. Yoon, J-H. and S.G.H. Phtlandor, The generation of coastal undercurrents, I. Deeanogrs. Soe Japan, in press, 1982.

(Received October 29, 1982 